\title{
9. AGE OF SUB-BOTTOM SULFIDE SAMPLES AT THE TAG ACTIVE MOUND ${ }^{1}$
}

\author{
Claude Lalou, ${ }^{2}$ Jean Louis Reyss, ${ }^{2}$ and Evelyne Brichet ${ }^{2}$
}

\begin{abstract}
Eight sulfide samples from eight cores from Trans-Atlantic Geotraverse (TAG) drilling areas 1, 2, 4, and 5 (ODP Leg 158) have been age dated using ${ }^{210} \mathrm{~Pb} / \mathrm{Pb}$ and ${ }^{230} \mathrm{Th} / 234 \mathrm{U}$ methods. In spite of the low number of samples, they give a comprehensible scheme of the possible evolution of the TAG active mound from $20 \mathrm{ka}$ to the present. In conjunction with previous geochronological results obtained from samples dredged or collected by the Alvin submersible research vehicle, a hypothesis for the development of this structure during the last $50 \mathrm{ka}$ is proposed.
\end{abstract}

\section{INTRODUCTION}

The Trans-Atlantic Geotraverse (TAG) hydrothermal complex is one of the largest deep-sea hydrothermal areas known. It is located at about $26^{\circ} 08^{\prime} \mathrm{N}$ at the base of the eastern wall of the median valley on the Mid-Atlantic Ridge. The hydrothermal field includes a presently active zone (the TAG mound, $3650 \mathrm{~m}$ depth) with black and white smokers, two high-temperature relict zones, the Alvin $(3550-3450 \mathrm{~m}$ depth) and Mir (3450 m depth) Zones, and a low-temperature discharge zone higher on the wall, at a depth of about $3150 \mathrm{~m}$ (Rona et al., 1993).

Dating of samples collected from these four zones (Lalou et al., 1995 ) indicates that hydrothermal activity began $\sim 125$ ka with episodic low-temperature events. High-temperature activity began about $100 \mathrm{ka}$ in the Mir Zone, and by $50 \mathrm{ka}$ all four zones were active. Only this 50-ka event is recorded in the only mound sampled in the relict Alvin Zone. This was followed by sporadic activity until $4 \mathrm{ka}$ for the low-temperature zone and the presently active mound and until $2 \mathrm{ka}$ for the Mir Zone. The presently active mound was reactivated about $80 \mathrm{yr}$ ago and currently includes high-temperature $\left(363^{\circ} \mathrm{C}\right)$ black smokers on top of the mound, lower temperature $\left(260^{\circ}-300^{\circ} \mathrm{C}\right)$ white smokers slightly east of the black smokers (the Kremlin area), and diffuse flow over much of the surface of the mound. The current lower temperature white smoker activity in the Kremlin area (dated at about $50 \mathrm{yr}$ ) is related to this last episode and, as shown by Tivey et al. (1995) and Edmond et al. (1995) can be explained by subsurface mixing of hot hydrothermal fluids with entrained seawater. Pervasive low-temperature discharge is present in the low-temperature zone on the eastern wall (Rona et al., 1984, 1993), which produces only patches of stained sediment rather than thick Mn-oxide deposits.

Most of the samples that have been previously analyzed were collected by submersible and so their location on the mound is well known. However, samples from two dredge hauls, one in the Alvin Zone and one on the eastern flank of the presently active mound, are less well-constrained in terms of location. Moreover, the oldest sample from the active mound (50,000 yr) was a dredged sample; hence, some uncertainty remains as to when hydrothermal activity began at this site, especially as all samples analyzed were collected at the surface of the mound or just under the surface.

Recent morphological studies (Humphris and Kleinrock, 1994; Humphris et al., 1995) indicate that the TAG active hydrothermal mound comprises two superposed terraces that may represent differ-

'Herzig, P.M., Humphris, S.E., Miller, D.J., and Zierenberg, R.A. (Eds.), 1998. Proc. ODP, Sci. Results, 158: College Station, TX (Ocean Drilling Program).

${ }^{2}$ Centre des Faibles radioactivités, CNRS-CEA, Avenue de la Terrasse, 91198 Gif sur Yvette cedex, France. Lalou: lalou@cfr.cnrs-gif.fr ent phases of active growth. The upper terrace is delineated by the 3650-m isobath and supports the cone on which the high-temperature activity is focused. The lower terrace, defined by the $3655-\mathrm{m}$ isobath, extends farther southeast and encompasses the Kremlin area of small white smoker chimneys.

The aim of Ocean Drilling Program (ODP) Leg 158 was to investigate the internal structure of the active hydrothermal mound. Seventeen holes were drilled in five areas: TAG-1, TAG-4, and TAG-5 on the upper terrace, and TAG-2 and TAG-3 on the lower terrace. (Fig. 1). Because of the nature of the underlying material, the drilling operations resulted in poor recovery. Nevertheless, the proximity of drill holes within each area has enabled the construction of composite vertical sections (Humphris et al., 1995). In this paper, we present the ages of samples from several drill holes and combine them with previously collected age data for surficial samples to reconstruct the history of hydrothermal activity at the TAG mound.

\section{MATERIAL AND METHODS}

We analyzed three sulfide samples from TAG-1 area (Samples 158-957F-1N-1, 7-9 cm, [1.07 m below seafloor, mbsf], 158-957C-

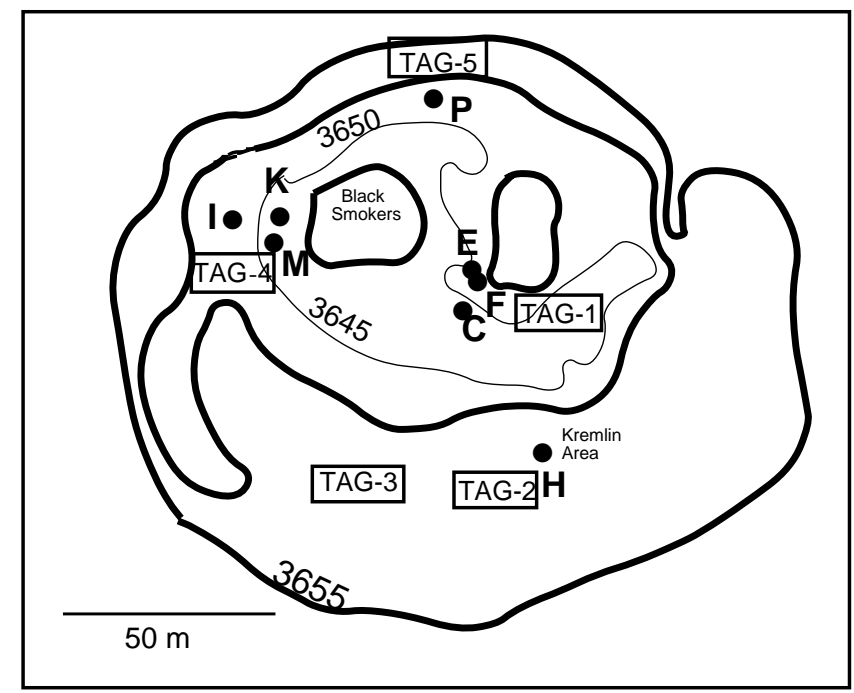

Figure 1. Schematic map of TAG active mound showing the limits of the upper and lower terraces (contours in meters) and the five TAG areas. The solid circles represent the position of the holes from which we obtained samples (after Humphris et al., 1995). 
$14 \mathrm{~N}-1,16-18 \mathrm{~cm},[40.36 \mathrm{mbsf}]$ and $158-957 \mathrm{E}-8 \mathrm{R} 1,1-3 \mathrm{~cm},[72.82$ mbsf]); one sulfide sample from TAG-2 area (Sample $158-975 \mathrm{H}-$ $5 \mathrm{~N} 1,7-8 \mathrm{~cm}$, [26.77 mbsf]); three sulfide samples in TAG-4 area (Samples 158-957K-1X-1, 42-44 cm, [0.42 mbsf], 158-957I-1N1, $7-11 \mathrm{~cm}$, [9.07 mbsf], and 158-957M-2R-1, 15-19 cm, [9.47 mbsf]); one in TAG-5 area (Sample 158-957P-6R-1, 22-24 cm, [26.73 mbsf]).

The two radiochronological methods used are described in detail by Lalou and Brichet (1987) and Lalou et al. (1993a). The first method is based on the decrease of ${ }^{210} \mathrm{~Pb}$ relative to stable lead and can be used for ages from 0 to about $200 \mathrm{yr}$. The particles formed in the hydrothermal plumes are very enriched in unsupported ${ }^{210} \mathrm{~Pb}$ (Finkel et al., 1980). We made the assumption (which we verified in various active hydrothermal fields) that the ratio ${ }^{210} \mathrm{~Pb} / \mathrm{Pb}$ is the same in the particles and in the forming sulfides independent of their lead content. Also, even if it is different from field to field, it is constant over time for each given field. So, if the sulfides act as a chemical closed system, the decrease of the ${ }^{210} \mathrm{~Pb} / \mathrm{Pb}$ ratio is representative of its age (Lalou and Brichet, 1987; Lalou et al., 1993a, 1993b). In order to evaluate whether a sample is young enough to be dated by the ${ }^{210} \mathrm{~Pb} / \mathrm{Pb}$ method, the presence of excess ${ }^{210} \mathrm{~Pb}$ relative to ${ }^{226} \mathrm{Ra}$ is determined by nondestructive gamma-spectrometry measurement. Only one sample was young enough for application of the $\mathrm{Pb}$ method (Sample $158-957 \mathrm{~F}-1 \mathrm{~N}-1,7-9 \mathrm{~cm}$ ). Initial conditions (conditions at $t_{0}$ ) for the ${ }^{210} \mathrm{~Pb} / \mathrm{Pb}$ method are determined from the value of this ratio measured in the particles issued from the black smokers, which were previously sampled by the submersible Alvin (sample Alvin 21-91; Lalou et al., 1993b).

For lead and ${ }^{210} \mathrm{~Pb}$ analysis (which must be measured on aliquots of the same solution), lead is measured by atomic absorption spectrophotometry (flame or graphite furnace), and ${ }^{210} \mathrm{~Pb}$ is measured through ${ }^{210} \mathrm{Po}\left({ }^{208} \mathrm{Po}\right.$ is used as a spike), by alpha spectrometry after waiting for secular equilibrium to be established between ${ }^{210} \mathrm{~Pb}$ and ${ }^{210} \mathrm{Po}$.

In the second method, the ${ }^{230} \mathrm{Th} /{ }^{234} \mathrm{U}$ method, the assumption is that when sulfides form, they include $U$ and no Th, so that the production of ${ }^{230} \mathrm{Th}$ from ${ }^{234} \mathrm{U}$ may be measured, provided also that the sample is a chemical closed system. It is useful for samples between about $50 \mathrm{ka}$ and $350 \mathrm{ka}$ but can be extended to younger ages (about 1 ka) with a lower precision $(\geq 10 \%)$, except in the case of very high uranium content or where a large quantity of sample is available.

The samples were first analyzed by semiquantitative X-ray diffraction analysis to establish the gross mineralogy, which in part reflects the uranium content. This is necessary to determine the quanti- ty of material for analysis, as well as the activity of the ${ }^{228} \mathrm{Th}-{ }^{232} \mathrm{U}$ spike necessary to obtain the best analytical conditions.

If the sample did not act as a closed system, a postdepositional introduction of uranium would tend to make it appear younger. This artifact is specially important for granular deposits and for metalliferous sediments, because of their possible rapid oxidation (Mills et al., 1994); hence, we used the central part of massive sulfide samples and avoided external, more oxidized parts. In addition, two subsamples were taken from different parts of each sample. If the two subsamples, which may have significantly different uranium content, give the same age within the statistical counting errors, then the age is considered good. Another artifact, which tends to make the sample appear older, is contamination by exogenic thorium. This may be determined through the detection of ${ }^{232} \mathrm{Th}$, which is not present at $t_{0}$. If the samples are very young or uranium poor, this contamination is critical.

The chemical and counting procedures are those described by $\mathrm{Ku}$ (1976) for carbonates and sediments, slightly modified for application to sulfide samples (Lalou and Brichet, 1987). For U and Th analysis, the sample is dissolved in $\mathrm{HCl}+\mathrm{NO}_{3}$ mixture with addition of a known activity of a spike ( ${ }^{232} \mathrm{U} \_228 \mathrm{Th}$ at equilibrium), the solution is centrifuged and the residue dissolved in a $\mathrm{HNO}_{3}+\mathrm{HClO}_{4}+\mathrm{HF}$ mixture. The purification and separation of $U$ and Th fractions are conducted through a series of hydroxide precipitations, and passing through resins. When two separate fractions ( $\mathrm{U}$ and $\mathrm{Th}$ ) are obtained, the last purification is achieved by extraction with TTA (thenoyltrifluoroacetone), and $\mathrm{U}$ and $\mathrm{Th}$ are separately deposited on aluminum foil. Their alpha activity is measured either in a gridded ion chamber or a semiconductor detector. Errors are given at the $1 \sigma$ level as generally used in such studies.

\section{RESULTS AND DISCUSSION}

The results are grouped by TAG drilling areas in Tables 1 and 2 . After carefully cleaning the sample's outermost part, two subsamples (1 and 2) of each sample were analyzed. Their relative positions in the samples and ages are given in Figure 2. Because we obtained only one piece of sulfide from each hole, the sample notation in the following text is simplified, and subsamples are designated as the hole letter followed by 1 or 2 . Generally, the measurements of the subsamples 2 are more reliable because, in addition to the mineralogical study, we used the results of subsample 1 to calculate the best conditions of analysis (that is, the weight of the sample and spike activity)

Table 1. Radiochemical results.

\begin{tabular}{|c|c|c|c|c|c|c|c|c|c|c|}
\hline $\begin{array}{l}\text { TAG } \\
\text { area }\end{array}$ & $\begin{array}{l}\text { Core, section, } \\
\text { interval }(\mathrm{cm})\end{array}$ & $\begin{array}{l}\text { Depth } \\
\text { (mbsf) }\end{array}$ & Mineralogy & $\mathrm{N}$ & $\begin{array}{l}{ }^{238} \mathrm{U} \\
(\mathrm{ppm})\end{array}$ & ${ }^{234} \mathrm{U} /{ }^{238} \mathrm{U}$ & $\begin{array}{c}{ }^{230} \mathrm{Th} \\
(\mathrm{dpm} / \mathrm{g})\end{array}$ & ${ }^{232} \mathrm{Th}$ & ${ }^{230} \mathrm{Th} /{ }^{234} \mathrm{U}$ & $\begin{array}{l}\text { Age } \\
\text { (ka) }\end{array}$ \\
\hline 1 & $957 \mathrm{~F}-1 \mathrm{~N}-1,7-9$ & 1.07 & $\mathrm{Ch}$ & $\mathrm{F} 1$ & $0.14 \pm 0.01$ & $1.020 \pm 0.137$ & $0.002 \pm 0.008$ & nd & $0.017 \pm 0.082$ & See Table 2 \\
\hline 1 & $957 \mathrm{C}-14 \mathrm{~N}-1,16-18$ & 40.36 & $\begin{array}{l}\text { P, An, Q } \\
\text { P, An, Q }\end{array}$ & $\begin{array}{l}\mathrm{C} 1 \\
\mathrm{C} 2\end{array}$ & $\begin{array}{l}4.08 \pm 0.11 \\
5.57 \pm 0.32\end{array}$ & $\begin{array}{l}1.159 \pm 0.024 \\
1.135 \pm 0.014\end{array}$ & $\begin{array}{l}0.068 \pm 0.005 \\
0.101 \pm 0.004\end{array}$ & $\begin{array}{c}0.037 \pm 0.01 \\
<0.0016\end{array}$ & $\begin{array}{l}0.020 \pm 0.002 \\
0.022 \pm 0.002\end{array}$ & $\begin{array}{l}2.15 \pm 0.18 \\
2.38 \pm 0.17\end{array}$ \\
\hline 1 & 957E-8R-1, 1-3 & 72.82 & $\begin{array}{c}\mathrm{P}, \mathrm{Q} \\
\mathrm{Q}, \mathrm{P}, \mathrm{S}\end{array}$ & $\begin{array}{l}\text { E1 } \\
\text { E2 }\end{array}$ & $\begin{array}{l}11.19 \pm 0.15 \\
18.05 \pm 0.47\end{array}$ & $\begin{array}{l}1.128 \pm 0.013 \\
1.156 \pm 0.009\end{array}$ & $\begin{array}{l}0.255 \pm 0.032 \\
0.363 \pm 0.016\end{array}$ & $\begin{array}{l}<0.0080 \\
<0.0026\end{array}$ & $\begin{array}{l}0.027 \pm 0.003 \\
0.024 \pm 0.001\end{array}$ & $\begin{array}{l}3.00 \pm 0.38 \\
2.59 \pm 0.13\end{array}$ \\
\hline 2 & $957 \mathrm{H}-5 \mathrm{~N}-1,7-8$ & 26.77 & $\stackrel{\mathrm{S}, \mathrm{P}, \mathrm{Q}}{\mathrm{P}}$ & $\begin{array}{l}\mathrm{H} 1 \\
\mathrm{H} 2\end{array}$ & $\begin{array}{l}1.68 \pm 0.07 \\
0.44 \pm 0.03\end{array}$ & $\begin{array}{l}1.080 \pm 0.056 \\
1.190 \pm 0.070\end{array}$ & $\begin{array}{l}0.171 \pm 0.011 \\
0.065 \pm 0.005\end{array}$ & $\begin{array}{l}<0.0065 \\
<0.0043\end{array}$ & $\begin{array}{l}0.128 \pm 0.010 \\
0.168 \pm 0.018\end{array}$ & $\begin{array}{l}14.80 \pm 1.20 \\
20.00 \pm 2.30\end{array}$ \\
\hline 4 & $957 \mathrm{~K}-1 \mathrm{X}-1,42-44$ & 0.42 & $\begin{array}{l}\text { S, P, M } \\
\text { S, P, M }\end{array}$ & $\begin{array}{l}\text { K1 } \\
\text { K2 }\end{array}$ & $\begin{array}{l}1.55 \pm 0.06 \\
1.43 \pm 0.04\end{array}$ & $\begin{array}{l}1.219 \pm 0.056 \\
1.124 \pm 0.031\end{array}$ & $\begin{array}{l}0.048 \pm 0.009 \\
0.037 \pm 0.004\end{array}$ & $\begin{array}{l}<0.0080 \\
<0.0033\end{array}$ & $\begin{array}{l}0.034 \pm 0.006 \\
0.031 \pm 0.004\end{array}$ & $\begin{array}{l}3.80 \pm 0.70 \\
3.42 \pm 0.40\end{array}$ \\
\hline 4 & 957I-1N-1, 7-11 & 9.07 & $\begin{array}{l}\mathrm{P}, \mathrm{M} \\
\mathrm{P}, \mathrm{M}\end{array}$ & $\begin{array}{l}\mathrm{I} 1 \\
\mathrm{I} 2\end{array}$ & $\begin{array}{r}25.45 \pm 0.42 \\
3.99 \pm 0.18\end{array}$ & $\begin{array}{l}1.146 \pm 0.008 \\
1.177 \pm 0.021\end{array}$ & $\begin{array}{l}1.043 \pm 0.047 \\
0.143 \pm 0.007\end{array}$ & $\begin{array}{c}<0.0060 \\
0.017 \pm 0.01\end{array}$ & $\begin{array}{l}0.049 \pm 0.002 \\
0.041 \pm 0.003\end{array}$ & $\begin{array}{l}5.40 \pm 0.26 \\
4.60 \pm 0.30\end{array}$ \\
\hline 4 & 957M-2R-1, 15-19 & 9.45 & $\begin{array}{c}\text { P, Ch } \\
\text { P, Ch, An }\end{array}$ & $\begin{array}{l}\text { M1 } \\
\text { M2 }\end{array}$ & $\begin{array}{l}37.04 \pm 0.61 \\
53.73 \pm 1.69\end{array}$ & $\begin{array}{l}1.142 \pm 0.008 \\
1.146 \pm 0.007\end{array}$ & $\begin{array}{l}1.237 \pm 0.050 \\
1.441 \pm 0.054\end{array}$ & $\begin{array}{l}<0.0058 \\
<0.0056\end{array}$ & $\begin{array}{l}0.040 \pm 0.002 \\
0.032 \pm 0.002\end{array}$ & $\begin{array}{l}4.40 \pm 0.20 \\
3.50 \pm 0.17\end{array}$ \\
\hline 5 & 957P-6R-1, 22-24 & 26.73 & $\mathrm{P}, \mathrm{Ch}, \mathrm{M}$ & $\begin{array}{l}\text { P1 } \\
\text { P2 }\end{array}$ & $\begin{array}{r}12.54 \pm 0.21 \\
8.70 \pm 0.45\end{array}$ & $\begin{array}{l}1.125 \pm 0.014 \\
1.185 \pm 0.031\end{array}$ & $\begin{array}{l}0.520 \pm 0.023 \\
0.440 \pm 0.043\end{array}$ & $\begin{array}{l}<0.0054 \\
<0.0060\end{array}$ & $\begin{array}{l}0.050 \pm 0.002 \\
0.058 \pm 0.006\end{array}$ & $\begin{array}{l}5.60 \pm 0.30 \\
6.47 \pm 0.73\end{array}$ \\
\hline
\end{tabular}

Notes: $\mathrm{An}=$ anhydrite, $\mathrm{Q}=$ quartz, $\mathrm{M}=$ marcasite, $\mathrm{Ch}=$ chalcopyrite, $\mathrm{S}=$ sphalerite, $\mathrm{P}=$ pyrite. The quoted errors are to a level of $1 \sigma ; \mathrm{dpm} / \mathrm{g}=$ disintegration per minute per gram, nd $=$ under the detection limit. 
Table 2. Results of the lead and ${ }^{210} \mathrm{~Pb}$ analysis.

\begin{tabular}{lccc}
\hline \multicolumn{1}{c}{ Sample } & $\begin{array}{c}\mathrm{Pb} \\
(\mathrm{ppm})\end{array}$ & $\begin{array}{c}{ }^{210} \mathrm{~Pb} \\
(\mathrm{dpm} / \mathrm{g})\end{array}$ & $\begin{array}{c}\text { Age } \\
(\mathrm{yr})\end{array}$ \\
\hline $\begin{array}{lccc}\text { 158-957F-1N-1, 7-9 cm } \\
\text { A 2191 (reference) }\end{array}$ & $13.7 \pm 1.0$ & $9.99 \pm 0.37^{*}$ & $16 \pm 4$ \\
\hline
\end{tabular}

Notes: No ${ }^{230}$ Th activity was detected in Sample F (see Table 1); A 2191 is a reference sample of particles issued from the black smokers (from Lalou et al., 1993b). * $=$ at date of recovery (October 1994).

to obtain the alpha spectrum in which the tails of the spikes $\left({ }^{232} \mathrm{U}\right.$ and ${ }^{228} \mathrm{Th}$ ) do not overlap the lower energy peaks.

\section{Analysis of Radiochemical Results}

\section{Age vs. Uranium Content}

First, it is important to verify that there is no systematic relation between $U$ content and age (i.e., that apparently younger ages do not correspond to anomalously high uranium content, which suggests a postdepositional introduction of uranium as discussed above). Figure 3 shows that the $U$ content of the samples is highly variable and that no simple relation between $U$ content and age exists. Samples with low $\mathrm{U}$ contents give some of the oldest ages (e.g., samples $\mathrm{H} 1$ and $\mathrm{H} 2$ ) as well as some of the youngest ages (e.g., samples F1 and F2). Samples with the highest $U$ content give intermediate ages. In some cases, there is a large difference of $U$ content between the two sub- samples. For samples I1 and I2, the subsample richer in U appears somewhat older, whereas the reverse is seen for samples E1 relative to $\mathrm{E} 2$ and $\mathrm{M} 1$ relative to $\mathrm{M} 2$. However, these differences in age are low, if not insignificant, as discussed in the next section. The only subsamples in which the difference in the measured age is significant are Samples $\mathrm{H} 1$ and $\mathrm{H} 2$; Sample $\mathrm{H} 1$ has slightly higher $\mathrm{U}$ content and is younger than $\mathrm{H} 2$.

\section{Comparison of the Ages of Subsamples 1 and 2}

Figure 4 presents the ${ }^{230} \mathrm{Th} /{ }^{234} \mathrm{U}$ ages with a $1-\sigma$ uncertainty of the subsamples grouped by drill hole and area. The ages of subsamples 1 and 2 from Holes C, E, K, and $P$ are in agreement, within $1-\sigma$ uncertainty. The ages of subsamples 1 and 2 from Hole I are slightly (5\% and $10 \%$, respectively) outside the $1-\sigma$ uncertainty limits. Subsamples 1 and 2 from Hole $\mathrm{H}$ are clearly older than the others and show significant differences in ages. Sample $\mathrm{H}$ is composed of two components, which were analyzed separately. Subsample 1 comes from a darker and more powdery zone of the sample, whereas subsample 2 was taken from a relatively fresh, lustrous, harder area. In terms of mineralogy, subsample 1 is composed dominantly of sphalerite, which is interpreted to be of secondary formation (Humphris, Herzig, Miller, et al., 1996), whereas subsample 2 is essentially pyrite. Hence, we consider that the age of this sample is $20 \pm 2.3 \mathrm{ka}$. The younger age ( $15 \pm 1 \mathrm{ka})$ may be the result of reworking of older material or a more recent event.
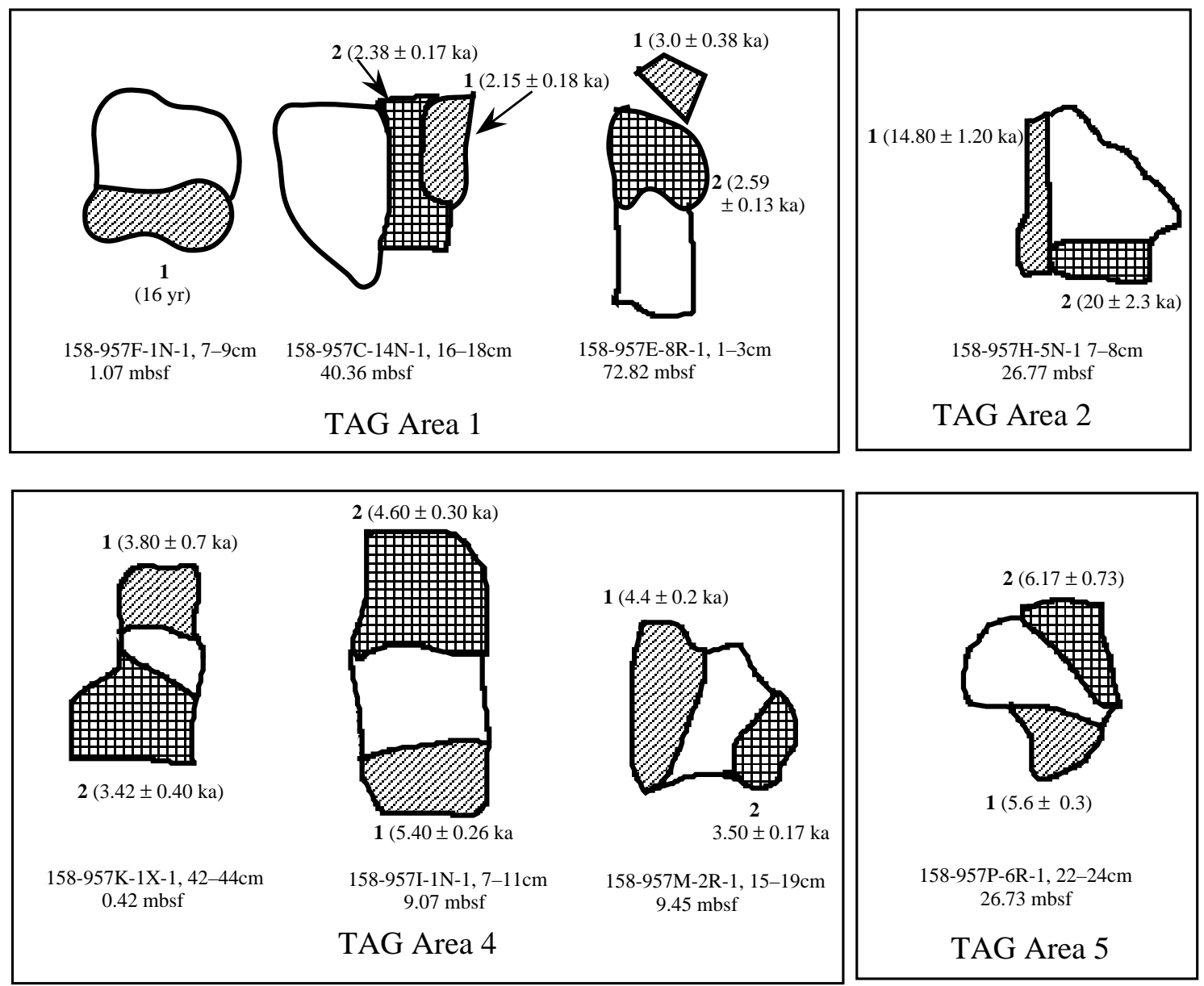

Figure 2. Schematic view of the samples with the positions and ages of subsamples 1 and 2. Diagonal hatching indicates subsample 1 and cross-ruled hatching indicates subsample 2 . 
Figure 3. Ages vs. U content. Large differences in U content between two subsamples is indicated by the lines with arrows (for example, between samples I1 and I2).
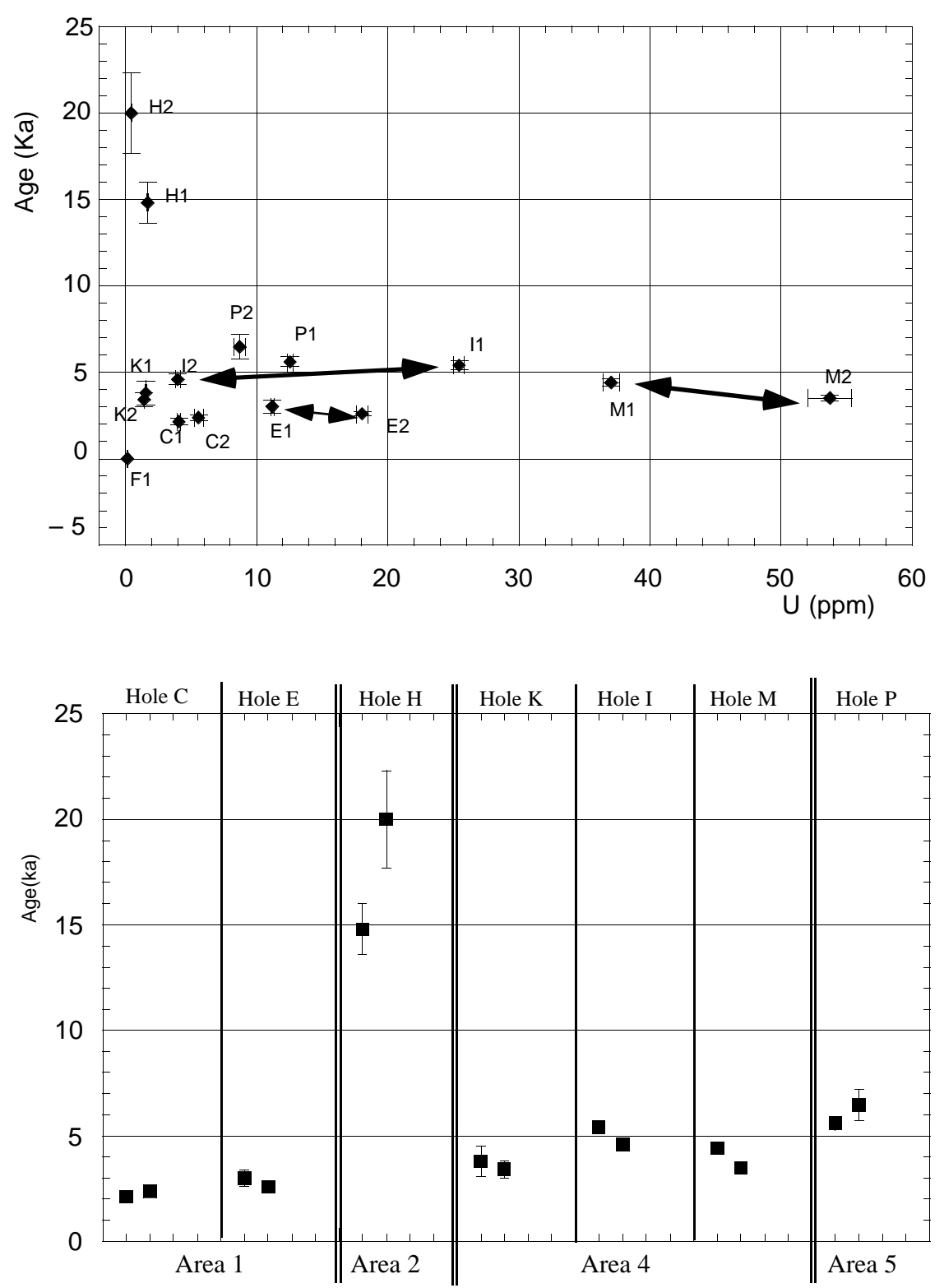

Figure 4. Ages with errors of $1 \sigma$ for subsamples 1 and 2 from each hole, with the holes grouped in their respective areas.

\section{Ages of Sub-Bottom Samples}

Figure 5 shows the calculated mean ages of the drilled samples (except for Sample $\mathrm{H}$ for which the two ages are kept) from the presently active mound plotted as a function of depth. On the same figure, we report the ages previously determined for samples from a 1985 dredge haul on the eastern edge of the mound and for samples recovered by submersibles (Lalou et al., 1993b). For ages younger than 100 $\mathrm{yr}$, the previously obtained dates were calculated at the date of sampling (1986), and our new date is given relative to the date of drilling (October 1994).

The TAG-1 area is closest to the presently active high-temperature black smokers. Sample F is from 1.07 mbsf and is composed of pure chalcopyrite. This is the youngest of the drilled samples and gives a ${ }^{210} \mathrm{~Pb} / \mathrm{Pb}$ age of $16 \pm 4 \mathrm{yr}$ relative to October 1994 , date of sampling (Table 2). This young age suggests that either this sample represents a piece of a chimney that has fallen from the top of the cone of focused black smoker activity or that there are other areas of high-temperature discharge on the upper platform. Sample $\mathrm{C}$ occurs at a depth of $40.36 \mathrm{mbsf}$ and is a pyrite-anhydrite-silica breccia. It has an age of 2.4 ka. Below 45 mbsf, recovery from Hole 957E was essentially a pyrite-silica breccia from which we obtained Sample E at $72.82 \mathrm{mbsf}$, which is composed of pyrite and quartz and has an age of $2.6 \mathrm{ka}$. This latter sample is believed to have come from the stockwork zone.

The TAG-2 area was drilled on the lower terrace near the Kremlin area of white smoker chimneys with bulbous shapes. Only one sample from Hole 957H, at 26.77 mbsf, was dated. As already discussed in the preceding section, subsample 2 is composed essentially of pyrite and quartz and has an age of $20 \mathrm{ka}$. However, subsample 2, which was analyzed especially because of its different appearance and in which sphalerite is the main component, gives an apparent age of 14 $\mathrm{ka}$. The sphalerite represents a late mineralization; however, its relation to the present-day white smoker activity cannot be established. It is interesting to note that these relatively old ages are found on the lower terrace, near the eastern slope where the dredge haul recovered the oldest samples for the TAG mound (between 25 and $15 \mathrm{ka}$ ).

The TAG-4 area is on the western flank of the mound in an area of low conductive heat flow (Becker et al., 1993). However, young sulfides (10 to $50 \mathrm{yr}$ ) were previously recovered from the surface of 


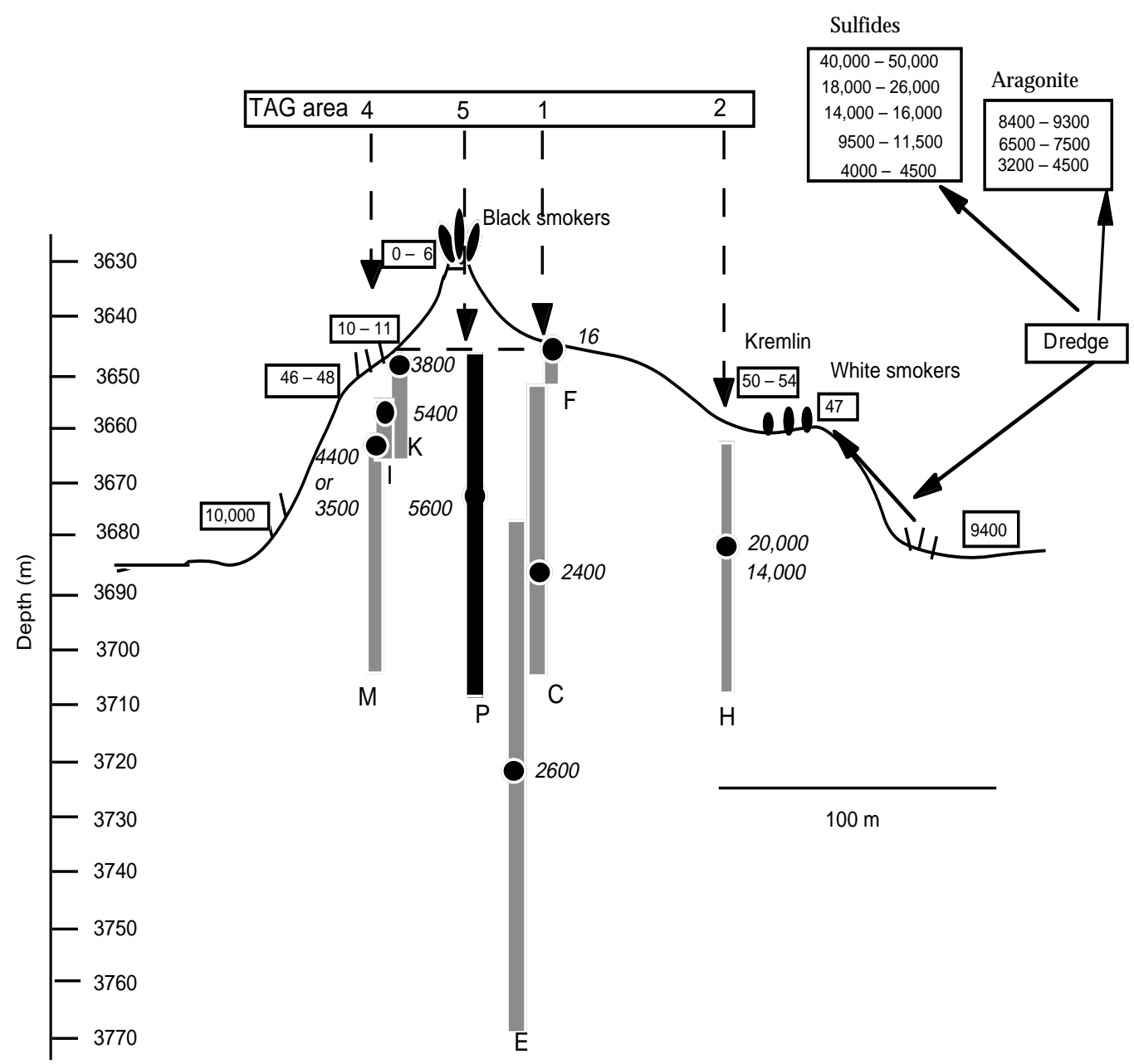

Figure 5. Cross section through the mound along a line through the black smokers and Kremlin area, showing the ages previously obtained (in boxes) and the positions of the drilled holes with ages (italics) at depths sampled. Hole P from TAG-5 was not located along this cross section, but was drilled behind the black smoker edifice; this core is shown in black and placed on the figure by its depth in relation to the other cores.

the mound in this area. Three drilled samples were dated: Sample K (0.42 mbsf) is composed of sphalerite, marcasite, and pyrite and has an age of $3.8 \mathrm{ka}$; Sample I ( $9.07 \mathrm{mbsf})$ is composed of pyrite and marcasite with an age of $5.4 \mathrm{ka}$, and Sample M (9.47 mbsf) is composed of pyrite and chalcopyrite and has an age of about $4 \mathrm{ka}$. A sample previously analyzed from the base of the talus in this area has an age of $10 \mathrm{ka}$.

Only one sample from Hole P (26.73 mbsf) was analyzed from the TAG- 5 area. This hole is situated northeast of the black smokers complex, at the outer limit of the upper terrace. It is composed of pyrite, chalcopyrite, and marcasite, and its age of $5.6 \mathrm{ka}$ is in accordance with the ages of the TAG-4 samples.

\section{What is the Reality of the Ages Found?}

Except for the ages found for the Hole 957H sample (20 ka and 14 $\mathrm{ka})$, all other ages are clearly younger than expected for samples collected from deep in a structure that began to form at least $50 \mathrm{ka}$. The ages are between 5.6 and $2.4 \mathrm{ka}$, which is not an optimal time period for the ${ }^{230} \mathrm{Th} /{ }^{234} \mathrm{U}$ method, especially when only small quantities of sample are available, because ${ }^{230} \mathrm{Th}$ activity in this time interval is between 0.05 to 0.02 that of uranium. Before discussing the implications of these ages, we need to verify that they are not geochemical artifacts.
Table 3. Comparison of ages obtained by the ${ }^{230} \mathrm{Th} /{ }^{234} \mathrm{U}$ method and by the ${ }^{226} \mathbf{R a} /{ }^{234} \mathrm{U}$ method.

\begin{tabular}{lcc}
\hline & \multicolumn{2}{c}{ Age (ka) } \\
\cline { 2 - 3 } $\begin{array}{c}\text { Hole, core, section, } \\
\text { interval }(\mathrm{cm})\end{array}$ & ${ }^{230} \mathrm{Th} /{ }^{234} \mathrm{U}^{*}$ & ${ }^{226} \mathrm{Ra} /{ }^{234} \mathrm{U}$ \\
\hline $957 \mathrm{H}-5 \mathrm{~N}-1,7-10$ & $20 \pm 2.3$ & $25.2 \pm 4$ \\
$957 \mathrm{E}-8 \mathrm{R}-1,1-3$ & $3.0 \pm 0.38$ & $3.3 \pm 0.3$ \\
$957 \mathrm{P}-6 \mathrm{R}-1,22-24$ & $5.6 \pm 0.3$ & $5.1 \pm 0.4$ \\
\hline
\end{tabular}

Note: $*=$ from Table 1.

To establish confidence in these ages, we tried another dating method on three samples through the measurement of ${ }^{226} \mathrm{Ra} /{ }^{234} \mathrm{U}$ ratio, although the method is not currently used because it is not as well established as others (Cherdyntsev, 1971). We reanalyzed Sample $\mathrm{H} 2$, the oldest one, Sample E, the deepest one (3.0 ka), and Sample $\mathrm{P}$, the oldest of the young samples $(5.6 \mathrm{ka})$. This method requires that, when formed, the sulfides do not contain any radium, which is certainly wrong for samples containing barite and possibly for others because in some respects the geochemistry of Ra is similar to that of $\mathrm{U}$. Anyway, if some ${ }^{226} \mathrm{Ra}$ is included when sulfide is forming, this will result in an increase of the ${ }^{226} \mathrm{Ra} /{ }^{234} \mathrm{U}$ ratio and, therefore, in an old apparent age. Another assumption is that the sample stays a closed 
system after formation. In an open system, ${ }^{226} \mathrm{Ra}$ as well as ${ }^{230} \mathrm{Th}$ may either enter or exit the system. Because of the very different geochemical behavior of the highly soluble $\mathrm{Ra}$ and the highly insoluble $\mathrm{Th}$, there is no reason that the same age should be obtained by the two methods.

The ages calculated by the two methods are given Table 3 . They are in complete agreement for Sample H2, at about $20 \mathrm{ka}$, as well as for the younger ones. This appears to validate the methods and the ages obtained.

\section{What Events are Recorded by These Ages?}

Figure 6 depicts an age axis of the last 25,000 yr, showing periods of high-temperature sulfide formation, periods of aragonite formation, and the different periods represented by the sub-bottom samples classified according to the area of sampling.

Rona and Speer (1989) and Rona et al. (1993) suggested a hypothetical sequence for the development of the active sulfide mound, taking into account the episodic nature of the heat supply. At the beginning, hydrothermal circulation is focused by the intersection of active axis-parallel marginal and axis-transverse faults. Then, as a result of the sporadic activity, a system of secondary conduits cools and allows metallic sulfide to precipitate. Tivey et al. (1995) suggested a flow model within the mound, derived from the mineralogy and chemistry of the deposit and taking into account the asymmetry of the mound. They introduced a secondary circuit because of the mixing of black smoker fluid with entrained seawater. Sample H2 from TAG2, dated at about $20 \mathrm{ka}$, may be considered to be contemporaneous with the end of the episode of high-temperature sulfide formation, at 26 to $18 \mathrm{ka}$. Rejuvenation (corresponding to the precipitation of sphalerite) is indicated by the high-temperature event dated between 16 and $14 \mathrm{ka}$. The samples from TAG-5, -4 , and -1 may correspond to the periods of cooling indicated by the aragonite deposits. During these cold periods, as they are no longer supported by a heating source, the sulfides precipitate in and clog the network of feeding channels.

\section{CONCLUSIONS}

Until now, apart from one sample dated at $10 \mathrm{ka}$, collected on the western talus of the mound, all other old samples come from the eastern part of the mound, that is, TAG-2. It is also in this area that we found the oldest sub-bottom sample, dated at $20 \mathrm{ka}$. We have previously established that the hydrothermal activity is sporadic and that, sometimes, between two periods of activity, the mound cooled completely.

Combining the eight ages from the drill core samples with previously collected data from surficial samples (Lalou et al., 1990, 1993b, 1995) we can further constrain the history of the mound (keeping in mind that these are few data points compared with the amplitude of the mound and the time span covered and that we have no mean to conclude about the closed system hypothesis except the fact that the two methods give the same age). Hydrothermal activity at the currently active TAG mound probably began at 50-40 ka, or earlier in the area of the lower terrace (Kremlin area). After a period of quiescence, a new period of activity began about $20 \mathrm{ka}$, as indicated by samples found in the same area. This is confirmed by the age of $20 \mathrm{ka}$ for Sample 158-975H-5N-1, 7-8 cm (26.75 mbsf) from the TAG-2 area. These data suggest that the lower terrace was the "first mound." Since then, it has been active every $\sim 5000 \mathrm{yr}$, developing high-temperature deposits from 20 to $5 \mathrm{ka}$. Later events reworked previously deposited material, as suggested by the $14 \mathrm{ka}$ age of part of Sample 158-975H-5N-1, 7-8 cm. Presently, there are no more high temperatures in this area, but only some lower temperature activity in the Kremlin white smokers, resulting from cooling of this part of the mound, which induces an entrance of seawater that mixes with the residual high-temperature flux.

Thereafter, the focus of activity shifted and the upper terrace began to form on the northern and western part of the lower terrace.

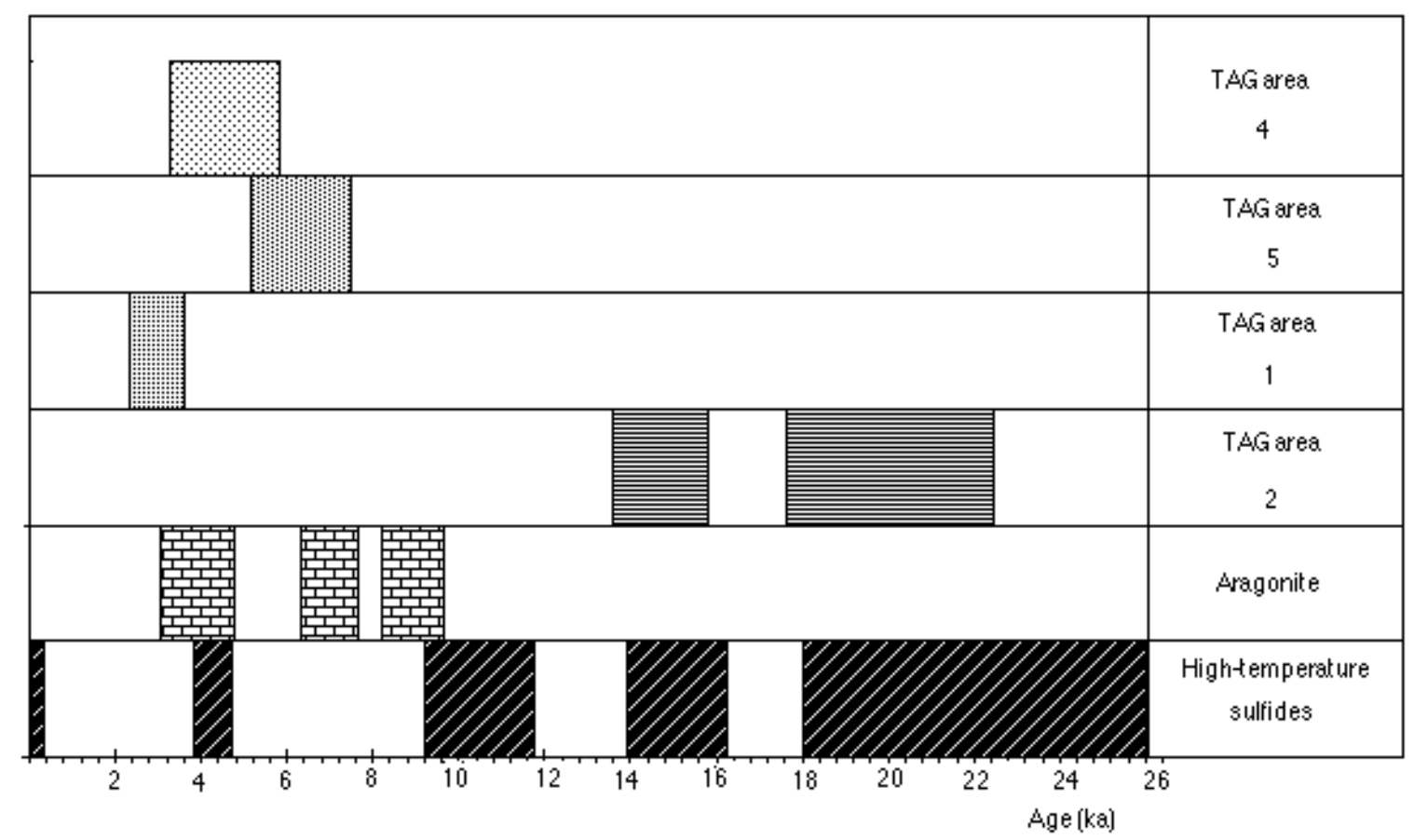

Figure 6. Age axis of the last 25,000 yr showing (from bottom to top): periods of high-temperature activity (sulfides), periods of cooling (indicated by aragonite deposits), ages of samples from TAG-2, ages of sample from TAG-1, age of sample from TAG-5, and ages of samples from TAG-4. 
This is corroborated by the ages of $5.6 \mathrm{ka}$ in Hole P in the TAG-5 area and 4-5 ka at Holes K, I, and M in the TAG-4 area, where a sample from the talus, previously dated at about $10 \mathrm{ka}$ seems to indicate that the ages of sub-bottom samples in TAG-4 more probably represent ages of clogging.

Very recent samples $(<50 \mathrm{yr})$ at the top of Core F $(0.42 \mathrm{mbsf})$ at the surface of TAG-4, are broken black smokers, that probably fell from the active Black Smoker Complex.

The two methods we used on the relatively young samples yielded the same age, which implies that, if young ages are a result of reworking, all the previous (older) sulfides must have been dissolved and that the conditions of precipitation were the same as when black smoker fluid enters open seawater.

\section{ACKNOWLEDGMENTS}

We thank Susan Humphris and Yves Fouquet, who sampled onboard ship for us, Susan Humphris also reviewed the very first draft of this paper. We acknowledge J. Channel, who corrected our English. H. Elderfield is acknowledged for his constructive review. Thanks are due to CNRS and CEA for the financial support of this work. This is CFR contribution No. 1914.

\section{REFERENCES}

Becker, K., and Von Herzen, R., 1993. Conductive heat flow measurements using ALVIN at the TAG active hydrothermal mound, MAR at $26^{\circ} \mathrm{N}$. Eos, 74:99.

Cherdyntsev, V.V., 1971. Uranium-234. In Israël Program for Scientific Translations: Jerusalem (Keter Press.). (Translated from Russian)

Edmond, J.M., Campbell, A.C., Palmer, M.R., Klinkhammer, G.P., German, C.R., Edmonds, H.N., Elderfield, H., Thompson, G., and Rona, P., 1995. Time series studies of vent fluids from the TAG and MARK sites (1986, 1990): Mid-Atlantic Ridge: a new solution chemistry model and a mechanism for $\mathrm{Cu} / \mathrm{Zn}$ zonation in massive sulfide ore bodies. In Parson, L.M., Walker, C.L., and Dixon, D.R. (Eds.), Hydrothermal Vents and Processes. Geol. Soc. Spec. Publ. London, 87:77-86.

Finkel, R.C., Macdougall, J.D., and Chung, Y.C., 1980. Sulfide precipitates at $21^{\circ} \mathrm{N}$ on the East Pacific Rise: Ra-226, Pb-210 and Po-210. Geophys. Res. Lett., 7:685-688.

Humphris, S.E., Herzig, P.M., Miller, D.J., Alt, J.C., Becker, K., Brown, D., Brügmann, G., Chiba, H., Fouquet, Y., Gemmell, J.B., Guerin, G., Hannington, M.D., Holm, N.G., Honnorez, J.J., Itturino, G.J., Knott, R., Ludwig, R., Nakamura, K., Petersen, S., Reysenbach, A.-L., Rona, P.A., Smith, S., Sturz, A.A., Tivey, M.K., and Zhao, X., 1995. The internal structure of an active sea-floor massive sulphide deposit. Nature, 377:713-716.

Humphris, S.E., Herzig, P.M., Miller, D.J., et al., 1996. Proc. ODP, Init. Repts., 158: College Station, TX (Ocean Drilling Program).
Humphris, S.E., and Kleinrock, M.C., 1994. Detailed morphology and distribution of venting at the active TAG hydrothermal mound, $26^{\circ} \mathrm{N}$, MidAtlantic Ridge. Eos, 75:660.

$\mathrm{Ku}$, T.L., 1976. The uranium-series method of age determination. Ann. Rev. Earth Planet. Sci., 4:347-379.

Lalou, C., and Brichet, E., 1987. On the isotopic chronology of submarine hydrothermal deposits. Chem. Geol. (Isot. Geosci. Sec.), 65:197-207.

Lalou, C., Reyss, J.L., and Brichet, E., 1993a. Actinide-series disequilibrium as a tool to establish the chronology of deep-sea hydrothermal activity. Geochim. Cosmochim. Acta, 57:1221-1231.

Lalou, C., Reyss, J.L., Brichet, E., Arnold, M., Thompson, G., Fouquet, Y., and Rona, P.A., 1993b. New age data for Mid-Atlantic Ridge hydrothermal sites: TAG and Snakepit geochronology revisited. J. Geophys. Res., 98:9705-9713.

Lalou, C., Reyss, J.-L., Brichet, E., Rona, P.A., and Thompson, G., 1995. Hydrothermal activity on a $10^{5}$-year scale at a slow-spreading ridge, TAG hydrothermal field, Mid-Atlantic Ridge $26^{\circ}$ N. J. Geophys. Res., 100:17855-17862.

Lalou, C., Thompson, G., Arnold, M., Brichet, E., Druffel, E., and Rona, P.A., 1990. Geochronology of TAG and Snakepit hydrothermal fields, Mid-Atlantic Ridge: witness to a long and complex hydrothermal history. Earth Planet. Sci. Lett., 97:113-128.

Mills, R., Elderfield, H., Thompson, J., Hinton, R.W., and Hyslop, E., 1994. Uranium enrichment in metalliferous sediment core from the Mid-Atlantic Ridge. Earth Planet. Sci. Lett., 124:35-47.

Rona, P.A., Hannington, M.D., Raman, C.V., Thompson, G., Tivey, M.K., Humphris, S.E., Lalou, C., and Petersen, S., 1993. Active and relict seafloor hydrothermal mineralization at the TAG hydrothermal field, MidAtlantic Ridge. Econ. Geol., 88:1989-2017.

Rona, P.A., and Speer, K.G., 1989. An Atlantic hydrothermal plume: TransAtlantic Geotraverse (TAG) Area, Mid-Atlantic Ridge crest near $26^{\circ} \mathrm{N} . J$. Geophys. Res., 94:13879-13893.

Rona, P.A., Thompson, G., Mottl, M.J., Karson, J.A., Jenkins, W.J., Graham, D., Mallette, M., Von Damm, K., and Edmond, J.M., 1984. Hydrothermal activity at the TAG hydrothermal field, Mid-Atlantic Ridge crest at $26^{\circ} \mathrm{N}$. J. Geophys. Res., 89:11365-11377.

Tivey, M.K., Humphris, S.E., and Thompson, G., 1995. Deducing patterns of fluid flow and mixing within the TAG active hydrothermal mound using mineralogical and geochemical data. J. Geophys. Res., 100:1252712555 .

Date of initial receipt: 6 May 1996

Date of acceptance: 20 January 1997

Ms 158SR-214 